\title{
A HISTÓRIA DO DESENVOLVIMENTO REGIONAL NO VALE DO SINOS: O CASO DE SAPIRANGA E SEUS PERCURSOS NO TEMPO
}

\author{
THE HISTORY OF REGIONAL DEVELOPMENT IN THE SINOS \\ RIVER VALLEY: THE CASE OF SAPIRANGA AND ITS COURSE \\ THROUGH TIME
}

Daniel Luciano Gevehr

Faculdades Integradas de Taquara - Taquara - RS - Brasil

\begin{abstract}
Resumo: O artigo analisa a dinâmica do desenvolvimento regional do Vale dos Sinos, localizado na Região Metropolitana de Porto Alegre (RS), a partir de um recorte espacial e temporal que é o município de Sapiranga, e sua trajetória de desenvolvimento desde o final do século XIX. Para tanto, buscamos discutir a historicidade desse contexto, investigando como os fatores regionais, nacionais e globais estão articulados no processo das transformações ocorridas em Sapiranga. Por meio dos condicionantes históricos, procuramos identificar os elementos que constituíram o desenvolvimento econômico, político, social e cultural do município, em especial, de seu espaço urbano. Atentamos de forma especial, para os aspectos presentes na esfera local e que assim nos permitem melhor compreender os percursos dessa comunidade no contexto regional do Vale do Rio dos Sinos.
\end{abstract}

Palavras-chave: História do Desenvolvimento Regional. Historicidade. Vale do Sinos. Sapiranga.

Abstract: The present study aims at analyzing the dynamics of regional development in the Sinos River Valley, located in the metropolitan region of Porto Alegre (RS), considering a specific spatial and temporal frame, which is the city of Sapiranga and its development course since the end of the 19th century. To do so, we have sought to discuss the historicity of such context, by investigating to what extent regional, national and global factors are articulated in the transformation process the city has gone through. Bu considering certain historical conditions, we have attempted to identify the elements that have contributed to the economic, political, social and cultural development of Sapiranga, specifically in as much as its urban area is concerned. We have paid special attention to the aspects pertaining to the local scope, which have enabled us to achieve a better understanding of the changes this community has gone through in the regional context of the Sinos River Valley.

Keywords: Regional Development History. Historicity. Sinos River Valley. Sapiranga.

\section{CONSIDERAÇÕES INICIAIS}

Concordamos com o historiador Ronaldo Vainfas (2002) quando este defende que, na análise historiográfica, o recorte espacial em nada diminui a importância de uma investigação, desde que a mesma tenha a preocupação de vinculá-la aos acontecimentos que cercam o espaço de investigação do historiador. É esse o caso de nosso estudo, que analisa o processo histórico do desenvolvimento ${ }^{1}$ ocorrido em Sapiranga, um dos mais importantes municípios do

\footnotetext{
1 Destacamos o aspecto polissêmico que apresenta o conceito de desenvolvimento na contemporaneidade. Nesse sentido, partimos do entendimento de que: "O desenvolvimento é um fenômeno complexo que ainda não tem uma definição esclarecedora e conclusiva sobre o seu
} 
setor calçadista do Brasil e que, em seu processo histórico de desenvolvimento, apresenta alguns elementos que o particularizam. Entre esses elementos podemos destacar a herança da imigração alemã do século XIX, a ruralidade, os impactos das migrações da segunda metade do século $X X$ e as transformações econômicas $e$ sociais impulsionadas pelo setor coureiro-calçadista.

Inicialmente, acreditamos que as transformações sofridas por Sapiranga não podem ser entendidas de forma isolada. Ao contrário, devem ser diretamente vinculadas aos fatos ocorridos tanto no Rio Grande do Sul quanto no Brasil, que, por sua vez, estão inseridos no contexto das transformações mundiais.

A partir desse ângulo, que procura estabelecer os vínculos entre o regional e o global, é que pretendemos percorrer a trajetória do desenvolvimento de Sapiranga. Por intermédio deste estudo, buscamos melhor compreender a história do desenvolvimento regionaf no Vale do Sinos, tendo como referência o caso de Sapiranga, que muito se aproxima dos demais municípios do Vale do Sinos, que apresentam a indústria calçadista como elemento importante de desenvolvimento econômico.

Para tanto, buscamos fundamentar nosso estudo em autores que discutem a questão do desenvolvimento regional e dos espaços das cidades, a partir da análise das diferenças ${ }^{3}$ e das desigualdades espaciais (DINIZ, 2009) próprias desses espaços. Em nossa pesquisa, partimos do pressuposto apresentado de que "cada região é uma região particular e distinta. De sorte que não há 'receita de bolo'

significado. Entretanto, tem uma função social importante que é promover o bem estar da humanidade. Entendemos que o conceito de desenvolvimento nunca será, nem poderá ser definido de maneira a agradar a todos, haja vista que se trata de um construto social com forte conteúdo ideológico e político, cujos valores e crenças são relativos a um determinado tempo e lugar. Porém, é importante considerar que quando falamos em desenvolvimento estamos ao mesmo tempo falando de crescimento, bem estar, sustentabilidade, bem como subdesenvolvimento, carências, privações e desequilíbrios, ou ainda, de mudança, modernidade e ocidentalização, podendo assim ter vários sentidos." (SANTOS, et al, 2012. p..58).

${ }^{2}$ Acerca da complexidade que envolve os estudos sobre o desenvolvimento regional, a partir de determinados recortes geográficos, nos valemos da pesquisa realizada apresentada por Pedro Bandeira (1999), que expõe uma importante análise sobre as diferentes variáveis presentes na dinâmica do desenvolvimento regional, em diferentes regiões do Brasil, como é o caso do Rio Grande do Sul. A partir disto, é que situamos Sapiranga na discussão.

${ }^{3} \mathrm{Na}$ perspectiva, de melhor compreender as diferenças regionais, vale destacar o exposto por PAIVA, quando afirma que "Tal como North procurou demonstrar, se buscamos acompanhar/projetar/planejar/ a dinâmica econômica dos territórios, a regionalização pertinente será a que resgata e diferencia as determinações da dinâmica econômica regional. E estas são: 1) o número, a distribuição espacial e a taxa de crescimento das atividades propulsivas num dado território; 2) o padrão de distribuição, absorção local e destinação da renda do território; 3) as características técnicas das atividades e cadeias produtivas que impulsionam (ou circunscrevem) o adensamento e complexificação das cadeias propulsivas regionais e sua transformação (ou não) em Arranjos Produtivos Locais; e 4) a capacidade das lideranças empresariais e dos trabalhadores que atuam nas atividades (e/ou cadeias; e/ou APLs) propulsivas regionais e sua transformação (ou não) em Arranjos Produtivos Locais; e 4) a capacidade das lideranças empresariais e dos trabalhadores que atuam nas atividades (e/ou cadeias; e/ou APLs) propulsivas e multiplicativas de reconhecerem os desafios interpostos ao desenvolvimento do território e articularem os instrumentos necessários a superação dos mesmos. e multiplicativas de reconhecerem os desafios interpostos ao desenvolvimento do território e articularem os instrumentos necessários a superação dos mesmos." (PAIVA, 2013, p.68) 
simples e unívoca para o 'desenvolvimento regional'. Porque não há um único regional, mas inúmeros." (PAIVA, 2013, p.17). Assim, entendemos que, para melhor compreender a dinâmica que envolve o desenvolvimento regional, precisamos, necessariamente, conhecer de forma mais aprofundada a realidade do espaço estudado e nesse caso, a historicidade desse espaço, buscando nele os caminhos e descaminhos em sua trajetória de desenvolvimento.

Figura 1. Mapa com a localização de Sapiranga (RS) - Brasil

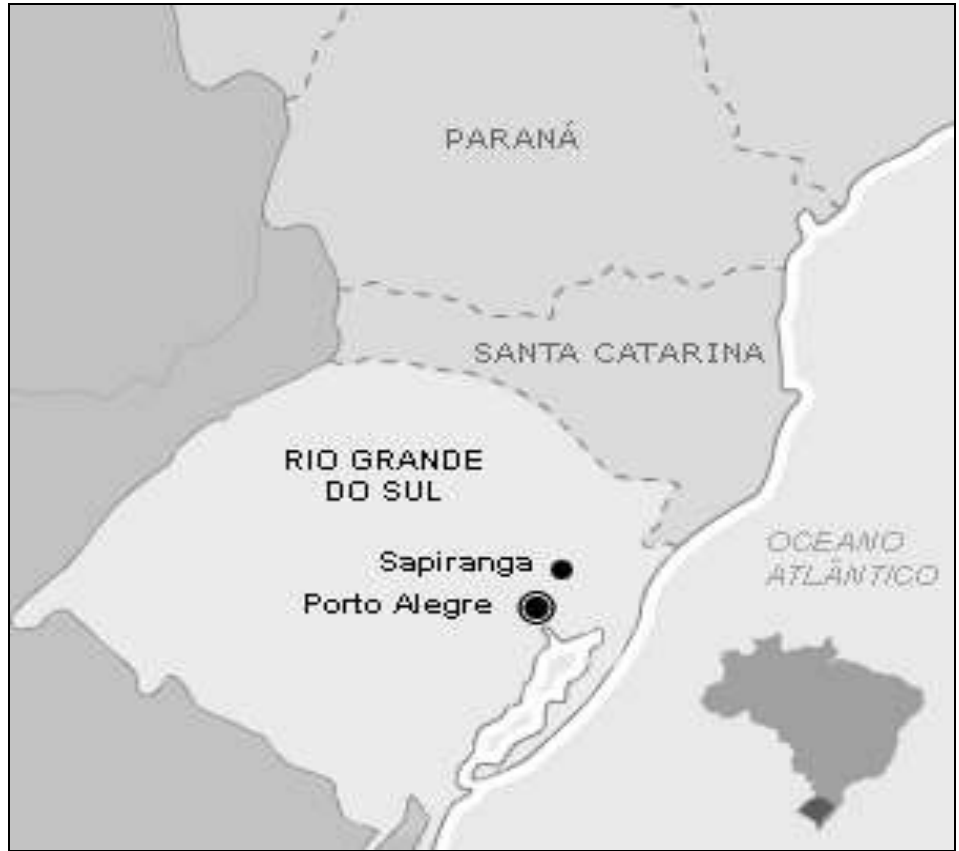

Fonte: Disponível em: http://imguol.com/2012/06/28/mapa-brasil-sul-riogrande-do-sul-sapiranga-1340913042953_300x300.gif.

Acesso em: 10 abr. 2016.

Iniciamos pensando esse espaço de acordo com a proposta apresentada por Octávio lanni (1999) para quem a cidade - e toda sua espacialidade - pode ser entendida como uma síntese privilegiada da Geografia e da História, assim como das relações existentes entre indivíduos e coletividades, do jogo das relações políticas e econômicas e da trama de produções culturais.

Para o sociólogo, é no espaço de interações da cidade que prevalecem o local e o nacional, que, por sua vez, são cada vez mais determinados pelo global. A cidade, na sua perspectiva, pode assumir diferentes papéis - simultâneos quase sempre, como de mercado, fábrica, centro de poder político, lugar de decisões econômicas. Pode ainda ser o laboratório das ideias científicas e filosóficas ou ainda espaço de experimentações artísticas.

Já para a antropóloga Josepa Giner (2004), o espaço da cidade - que em nosso caso é Sapiranga - é um lugar de práticas cotidianas, que nos permite acessar conhecimentos valiosos sobre seu funcionamento. Para ela, esse é o espaço onde podemos estabelecer os vínculos entre macroprocessos e a textura e fabricação da experiência humana. A relação que se estabelece entre os macroprocessos e aquilo que acontece no âmbito regional é, dessa forma, um dos propósitos da discussão realizada neste estudo. 
Ainda para Giner (2004, p.35) "la cidad representa el punto de encuentro, el nodal point, el momento máximo de concentración e integración de lãs referidas formas de espacialización social". É nesse espaço, entendido como a cidade, que ocorre grande parte das relações cotidianas, que por sua vez, estão relacionadas com a pauta das questões globais.

Nesse sentido, nosso estudo procura analisar como as questões teóricas sobre desenvolvimento endógeno e exógeno (OLIVEIRA; LIMA, 2003) aplicam-se no espaço estudado, que é o Município de Sapiranga. Inserido no contexto de desenvolvimento econômico do Vale do Sinos, Sapiranga apresenta indicadores que nos permitem acompanhar a trajetória das transformações em seu espaço. A partir da história desse desenvolvimento, queremos investigar o exemplo percorrido por esse espaço, que pode ser entendido como um exemplo das singularidades do desenvolvimento regional.

\section{TEXTO E CONTEXTO: AS ORIGENS HISTÓRICAS DO ESPAÇO}

Nossa análise sobre o processo de desenvolvimento de Sapiranga parte do ano de 1874, quando se deu o desfecho do conflito Mucker, e muitos colonos Mucker venderam suas terras e migraram para regiões vizinhas, como Três Coroas, Igrejinha e Gramado, entre outras localidades. Outros permaneceram em Sapiranga. Vale ressaltar que o episódio dos Mucker (1868-1874), que foi liderado por Jacobina Maurer, marcando profundamente a dinâmica da Antiga Colônia Alemã de São Leopoldo e, durante várias décadas, o lugar onde se desenvolveria Sapiranga ficou estigmatizado como o "lugar dos Mucker" e o "lugar de Jacobina".

O conflito Mucker marcou de forma decisiva o desenvolvimento da localidade, afinal foram vários anos em que a comunidade viu-se abalada pelo clima de tensão e violência que levou muitos colonos à falência de suas atividades agrícolas.

Após o conflito, os moradores das imediações do Ferrabraz sentiram-se abalados com os acontecimentos, o que os levou a retraírem-se e a dedicarem-se ao trabalho, na tentativa de esquecer o passado. Como exemplo da tentativa de esquecimento, encontramos a mudança do nome da localidade em que ocorreu o conflito. ${ }^{4}$ Logo após o desfecho do conflito, em 1874, a denominação Fazenda Padre Eterno passou a designar uma pequena região do planalto, atrás do Morro Ferrabraz. Com o advento da República, em 1889, a comunidade passaria e se orientar pelo lema positivista da "ordem e progresso", que orientava o governo federal. No caso do Rio Grande do Sul, sabemos que o positivismo se fez muito presente no âmbito político e cultural, o que, naturalmente, influenciou o

\footnotetext{
$4 \mathrm{Na}$ história do Brasil, foram vários os exemplos dessa tentativa de construir uma nova denominação para as localidades que presenciaram conflitos marcantes e que abalaram a vida de seus moradores. Um desses exemplos pode ser encontrado no estudo realizado por Janice Theodoro em relação a Canudos, na Bahia. A autora aponta para a importância do "apagamento" do local em que ocorreu o conflito em 1897. Numa tentativa de apagar da memória coletiva o passado de Canudos, o território ocupado pelo arraial foi coberto pelas águas do açude de Cocorobó em 1968, em pleno regime militar. Frequentemente, no período das secas, podem ser vistas na área cruzes, ossadas e crânios, muros, e peças de artilharia. (THEODORO, 1997)
} 
desenvolvimento das diferentes regiões do estado, como foi o caso do Vale do Sinos.

Sobre esse processo, podemos pensar em Arruda (2000, p.137), quando esse afirma que "os mapas são artefatos culturais, carregados de subjetividade e dos valores culturais da sociedade que os criou, e essencialmente das marcas do poder". Conforme veremos, as transformações sofridas pela localidade manifestavam parte dos interesses presentes em diferentes "tempos e espaços" e que, dessa forma, materializavam-se nas mudanças sofridas nos diferentes lugares que constituíam Sapiranga. A nomeação dos lugares da cidade ${ }^{5}$ acompanham esse processo, na medida em que as novas gerações, inscritas em diferentes épocas e contextos, modificam a paisagem urbana e sua organização, buscando, com isso, legitimar seus interesses. Nesse caso, " [...] a nomeação de lugares provocava uma luta, ou melhor, fazia parte de um conflito em torno de representações espaciais existentes na sociedade" (Ibidem, p.150).

A localidade de Padre Eterno atualmente abrange uma pequena parte das terras do Município de Sapiranga, sendo que a maior parte pertence ao Município de Morro Reuter. Nos dias atuais, a localidade está desmembrada em Padre Eterno, Padre Eterno Alto e Padre Eterno Baixo. Para essas localidades, migraram muitos dos colonos envolvidos no conflito de 1874 e que eram adeptos dos Mucker.

Com isso, o lugar passou a ter diversas denominações, como Fazenda Leão (Leonerhof), Linha Ferrabraz, Linha do Verão, Linha da Bica, Terras do Sapiranga, Picada Hartz e Porto Palmeira. Já a denominação de Sapyranga apareceu somente no final do século XIX. ${ }^{6}$ Essas mudanças na denominação das localidades faziam parte de uma estratégia que tinha como finalidade dar uma nova identidade para o lugar, que não estivesse mais diretamente ligado aos Mucker.

Percebemos, assim, que a população tentava apagar da memória coletiva o passado Mucker, que a identificava como descendente dos Mucker, contrariando a imagem do colono ordeiro, descendente de alemães. Essa atitude revela que a população acreditava que, por meio do trabalho, poderia recuperar a dignidade e os anos de atraso provocados pelo conflito.

Logo após o desfecho do conflito Mucker, os sapiranguenses teriam abaladas mais uma vez as suas vidas. Com a Revolução Federalista (1893-1895) as casas de muitos colonos seriam atacadas e seus pertences muitas vezes saqueados pelos federalistas vindos dos Campos de Cima da Serra, os quais invadiam a região em busca de cavalos e alimentos. Conforme nos mostram os escritos do pastor evangélico-luterano Wilhelm Bartel, na Crônica da Comunidade Evangélica de Sapiranga - 1924 - 1926, esses acontecimentos marcaram profundamente a vida da comunidade do final do século XIX, que presenciou dois conflitos importantes de nossa história: o Conflito Mucker e a Revolução Federalista.

\footnotetext{
${ }^{5}$ É importante destacar que quando nos referimos à cidade, estamos fazendo referência a todo o processo que constitui o fenômeno urbano, que, de acordo com a Choay (2015, p.18), compreende não apenas a materialidade exposta no espaço urbano, mas também seus imaginários, que nos permitem descortinar o espaço urbano como uma produção tipicamente humana, dotada de formas, sentidos e significados, que se traduzem por meio da arquitetura das cidades.

${ }^{6}$ Encontramos no Arquivo da Comunidade Evangélica de Sapiranga uma Ata de Casamento de 1891, identificando a localidade como Sapyranga. Este é o primeiro documento em que a denominação Sapiranga aparece. Porém, essa denominação passa a ser empregada de forma recorrente somente a partir de 1903, com a inauguração da estação do trem.
} 
Figura 2. Vista parcial da cidade com o Morro Ferrabraz ao fundo.

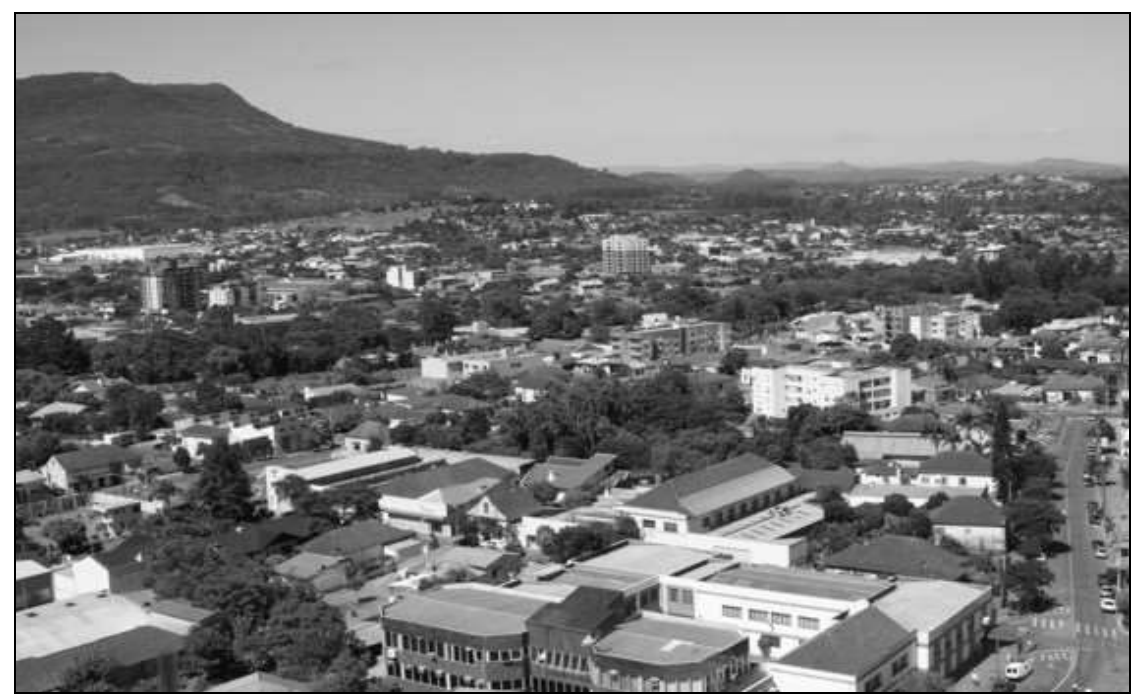

Fonte: Disponível em: http://www.rgdosul.com.br/fotos/sapiranga.jpg. Acesso em: 10 abr. 2016.

Com as transformações ocorridas na política nacional a partir de 1889, ano da Proclamação da República, instalou-se um governo autoritário, com inspiração no positivismo de Augusto Comte, matriz que orientava os passos do governo. No caso do Rio Grande do Sul, o governo buscou incentivar o desenvolvimento econômico de forma global, privilegiando a dinamização do setor industrial e o desenvolvimento urbano, que deveria se contrapor ao Estado predominantemente voltado para o setor agropecuário e a uma população que predominantemente vivia na zona rural.

Atentamos para o fato de que essas transformações faziam parte do programa de governo implementado ao longo da República Velha no Brasil (18891930) e no qual serão bastante visíveis as preocupações com a urbanização e a modernização dos espaços - até então considerados atrasados -, especialmente do ponto de vista econômico.

Inserida nesse contexto de urbanização e modernização ocorrida no Brasil durante a República Velha no Brasil, destacamos a promulgação da Lei $n^{\circ} 3$ de 24 de março de 1897, que estabeleceu o Código de Posturas Municipais de São Leopoldo. Essa lei, promulgada pelo então Intendente Municipal Major Epifânio Orlando de Paula Fogaça, procurava estabelecer medidas para o controle social da população do município, em especial da população urbana. Os artigos tratavam de diversas questões, como a correta utilização dos animais como meio de transportes nas vias públicas, a construção e disposição das residências e estabelecimentos comerciais, a manutenção da limpeza pública.

O rio dos Sinos recebeu especial atenção na lei de 1897, permitindo-se a utilização do rio para se lavar roupa, embora a população necessitasse respeitar algumas normas. Entre as normas apresentadas, encontrava-se a proibição de 
expressões injuriosas ou indecentes, motins ou qualquer ato que ofendesse a paz e a moralidade pública, sob pena de multa de $5 \$ 000$ e 2 dias de prisão. Deveriam ainda ser observadas as condições em que os moradores de São Leopoldo poderiam se banhar nas águas do rio do Sinos. Segundo a lei, era permitido o banho em suas águas, desde que as pessoas vestissem calções ou peças semelhantes que cobrissem as partes do corpo. Ficava terminantemente proibido proferir palavras ou gestos obscenos no local, sob pena de prisão durante 24 horas, além de multa de $20 \$ 000$.

Não desconhecemos o fato de que já durante o período final do Império, em especial na sua última década, havia, no Brasil, uma preocupação, por parte do governo, de modernizar a economia do país, favorecendo a implantação industrial. Como exemplo desse desenvolvimento, sabemos que a indústria brasileira teve seu primeiro surto apreciável no último decênio do Império (1880-1889), coincidindo com esta fase já assinalada de geral recrudescimento das atividades do país. (PRADO JÚNIOR, 2004) Essa fase de desenvolvimento industrial no Brasil iria se prolongar na República, especialmente nos primeiros anos do novo regime político, no qual ele identifica uma verdadeira "febre de iniciativas" em relação à modernização da economia nacional.

\section{AS RELAÇÕES ENTRE O DESENVOLVIMENTO ECONÔMICO E SOCIAL}

Considerando que a complexidade urbana é um fenômeno complexo e que se constitui num elemento central da problemática contemporânea, "tanto do ponto de vista da realização do processo de acumulação capitalista - e, por consequência, de justificativa das ações do estado em direção à criação dos fundamentos da reprodução - quanto do ângulo da (re)produção da vida, que se realiza em espaços-tempos delimitados reais e concretos" (CARLOS, et al, 2014, p. 14).

Consideramos oportuno, ainda, lembrar que o tema do desenvolvimento econômico regional não tem se apresentado como um problema relevante para a maioria dos historiadores brasileiros, que têm priorizado, na maioria das vezes, a análise a partir "de modelos econômicos e suas inter-relações com variáveis como sustentabilidade e crescimento econômico" (VIEIRA; SANTOS, 2012, p.346). Nesse sentido, nossa pesquisa busca contribuir para a ampliação do debate interdisciplinar, que permite a história, analisar a dinâmica do processo de desenvolvimento de uma determinada região ${ }^{7}$, para além de seus aspectos puramente econômicos.

\footnotetext{
7 Destacamos que, neste estudo, "região" é compreendida na perspectiva proposta por Haesbaert (2014, p. 25) para quem "pensar em região [...] é pensar, antes de tudo, nos processos de regionalização - seja focalizando-os como simples procedimento metodológico ou instrumento de análise proposto pelo pesquisador, seja como dinâmicas efetivamente vividas e produzidas pelos grupos sociais". Além disso, Haesbaert (2014, p. 125) chama a atenção para o fato de que "na busca do(s) elemento(s) integrador(es), principal(is) responsável(is) pela "síntese" ou, de forma mais coerente, pela integração, unidade e - ou coesão - ou como preferimos aqui, articulação regional -, os geógrafos, especialmente discípulos altamente simplificadores de Vidal de la Blache, muitas vezes caíram na esquematização generalista de um método pretensamente complexo, que tornou a análise [...] regional um mero acúmulo de "gavetas", em que se sucediam elementos como relevo, clima, população, economia, etc.".
} 
Nessa perspectiva, é que buscamos percorrer as transformações sofridas em Sapiranga, e quais os elementos envolvidos nessa dinâmica de desenvolvimento do município.

Quanto ao desenvolvimento econômico que se verificou em Sapiranga, então $5^{\circ}$ Distrito de São Leopoldo ${ }^{8}$, percebemos que, desde o final do século XIX, a agricultura era a atividade predominante, destacando-se de forma especial o cultivo da mandioca.

O progresso experimentado pelo setor primário logo abriu caminho para o desenvolvimento de outras atividades que diversificaram de forma bastante expressiva a economia local. Sapiranga tornava-se, cada vez mais, dinâmica e integrada a São Leopoldo e Porto Alegre, centros econômicos importantes desse período. Fatores regionais e da própria localidade foram, dessa forma, elementos decisivos no desenvolvimento de Sapiranga.

Para Claudia Wasserman (2004), no caso do Rio Grande do Sul, a República Velha caracterizou-se como uma fase de grande prosperidade econômica, baseada no desenvolvimento das atividades primárias ligadas à pecuária, no crescimento da agricultura colonial e do cultivo do arroz no litoral, marcadas por crises pontuais, mas que, basicamente, proporcionaram o incremento da implantação do capitalismo no Rio Grande do Sul, com a instalação das primeiras unidades fabris e consolidação de qual seria o perfil industrial do estado, a expansão do mercado e o crescimento da urbanização.

Ainda de acordo com a análise proposta por Wasserman, o Rio Grande do Sul, ao longo da República Velha, foi marcado por sua posição singular na estrutura da nação. Não estava no mesmo patamar de desenvolvimento dos centros urbanos como São Paulo e Rio de Janeiro, mas, ao mesmo tempo, não se alinhava com estados do nordeste e norte do país. Dentro dessa conjuntura econômica, a política do PRR encontrou campo fértil para se desenvolver e nos quais veremos seus dois maiores símbolos: Júlio de Castilhos e Borges de Medeiros. Todavia, esse sistema político precisou enfrentar os conflitos que marcaram o período no estado, como são os exemplos da Revolução Federalista de 1893 e da Revolução de 1923 entre "legalistas" e libertadores.

Nesse contexto de transformações em Sapiranga, a indústria calçadista teve espaço para progredir cada vez mais, atendendo aos pedidos não apenas da comunidade, mas também de outras regiões que compravam seu produto. As primeiras décadas do século $X X$ acompanharam uma mudança considerável na economia sapiranguense, que apresentava um setor industrial cada vez mais desenvolvido, o que também provocou o aumento de sua população urbana.

Nesse caso, percebemos claramente aquilo que Abreu (2014, p.30) apresenta quando afirma que "é fundamental que não esqueçamos jamais que a História de um lugar é o resultado da ação, num determinado momento e sobre um determinado espaço, de processos que atuam em escalas que são ao mesmo tempo desiguais e combinadas." Nessa mesma linha interpretativa, o autor destaca

\footnotetext{
${ }^{8}$ Sapiranga foi o $5^{\circ}$ Distrito de São Leopoldo no período compreendido entre 28 de março de 1890 e 15 de dezembro de 1954, quando o então governador do Estado, Ernesto Dornelles, sancionou a lei que criava o Município de Sapiranga. A posse do primeiro prefeito e vice-prefeito realizou-se em 28 de fevereiro de 1955, data em que se comemora atualmente a emancipação política do município.
} 
que "ela precisa relacioná-los a processos mais gerais, que atuam em escalas mais amplas (regional, nacional, global) da ação humana." (Ibidem, p.30).

A partir dessa teoria, podemos entender o desenvolvimento do setor industrial em Sapiranga a partir de sua inserção na política nacional de desenvolvimento da República Velha. De acordo com o Censo Geral e Completo das Indústrias, realizado em 1907, o Brasil, no início do século XX, alcançava bons resultados na sua produção industrial. Encontramos, nesse ano, 3.258 estabelecimentos industriais com um capital empregado de $665.663 \$ 000 \mathrm{e}$ empregando 150.841 funcionários.

Nessa dinâmica do desenvolvimento industrial em Sapiranga - em que a agricultura dava sinais de regresso e a indústria prosperava - mereceu destaque Jakob Biehl, um alemão que chegou ao Brasil em 1866, estabelecendo-se como ferreiro em Sapiranga. Logo transformou sua ferraria numa pequena indústria metalúrgica que, em 1920, empregava cerca de quinze funcionários, sendo então a principal indústria local. Seu pioneirismo no setor industrial fez com que Jacob Biehl fosse chamado de "pai da indústria" de Sapiranga.

Para termos uma noção desse desenvolvimento, observamos que, na década de 1920, existiam em Sapiranga 121 atafonas que fabricavam farinha de mandioca, vendida especialmente para São Paulo e Rio de Janeiro. ${ }^{9}$ A economia sapiranguense articulava-se cada vez mais com o mercado nacional e também com o internacional. Observamos que, embora a atividade industrial tenha se desenvolvido consideravelmente nas primeiras décadas do século $\mathbf{X X}$, a atividade agrícola não encerrou suas atividades. Especialmente o cultivo de mandioca continuou se desenvolvendo, tendo em vista a fabricação de farinha. Nesse contexto, aliava-se a produção agrícola com a atividade industrial crescente em Sapiranga.

As transformações ocorridas no cenário sapiranguense fazem parte de uma série de mudanças ocorridas no âmbito do Estado do Rio Grande do Sul e também do contexto internacional, no qual observamos intensas transformações, como por exemplo, nos Estados Unidos e na Europa.

Durante as primeiras décadas do século $X X$, o PRR foi o grande responsável pela modernização dos meios de transportes e das comunicações. A capital do estado viveu os encantos da Belle Epòque, demonstrando sua modernização e novidades, como o bonde elétrico, o teatro e o cinema, as partidas de futebol (sendo que o próprio PRR incentivava as partidas de futebol como meio de disciplinamento e de integração do estado) que culminaram com a criação de dois importantes clubes de futebol, o Grêmio (1903) e o Internacional (1909). A Exposição Estadual de 1901 mostrou aos gaúchos o crescimento e a diversificação das atividades econômicas. Eram mais de 300 fábricas participantes, entre elas, fábricas de móveis, banha, charutos, vinho, cerveja, tecidos, couros, vidros, chapéus, conservas e outros tantos bens de consumo, sendo que a maioria destes estabelecimentos localizava-se em Porto Alegre, Pelotas e Rio Grande, considerados, então, centros de difusão industrial.

Observamos que, na década de 1940, a agricultura regredia consideravelmente em Sapiranga, principalmente em razão do desenvolvimento da

\footnotetext{
${ }^{9}$ O setor coureiro-calçadista, naquele ano, alcançou uma produção total de 96.998 pares de calçados, perfazendo $24,8 \%$ do total de impostos recolhidos no município. (FLECK, 1994)
} 
indústria calçadista, que prosperava desde a década de 1930, provocando cada vez mais a saída das pessoas do campo para a cidade, contribuindo, assim, para o declínio da produção agrícola. Nesse contexto, a indústria ocupava, progressivamente, não apenas destaque na produção, como também ocupava cada vez mais a mão de obra, antes agrícola.

O processo de desenvolvimento industrial que vinha ocorrendo no Vale dos Sinos já na década de 1920 implicava uma nova realidade social, com o surgimento do trabalhador assalariado. Esse novo elemento da dinâmica social permitia não só o aumento da produção industrial como também ampliava o mercado consumidor, agora assalariado. ${ }^{10}$

Figura 3. Vista aérea de Sapiranga atualmente

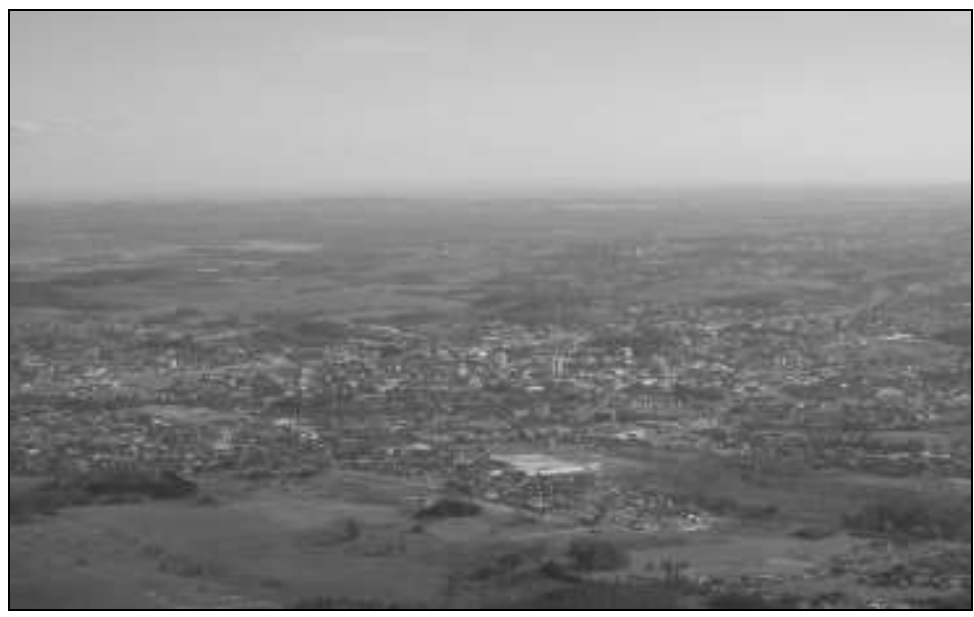

Fonte: Disponível em:

http://img.photobucket.com/albums/v340/pampa/sapiranga32.jpg.

Acesso em: 24 jan. 2016.

Como parte das transformações que se deram em nível local, cabe destacar a ampliação da oficina de Adolfo Kautzmann em 1922, o que o levou a empregar mais funcionários e inaugurar oficialmente a primeira fábrica de calçados de Sapiranga. Essa iniciativa, embora individual, revela que a economia sapiranguense dava claros sinais de mudanças.

Até o censo de 1940, não se encontram estatísticas precisas sobre a distribuição da população brasileira, especialmente no que se refere à divisão entre rural e urbano. ${ }^{11}$ Mesmo após o censo de 1940, é muito difícil fazer tal distinção, uma vez que os censos consideravam como população urbana aquela que vivia em

10 Em 1920, a população de Sapiranga era de 2.856 habitantes. No início dos anos de 1920, existiam 539 prédios construídos em Sapiranga, dentre os quais estavam residências e estabelecimentos industriais e comerciais.

${ }^{11}$ Sobre a relação urbano-rural, atentamos para os estudos de Sposito $(2014$, p.134) quando essa afirma que [...] não é possível se ver a cidade atual como unidade, porque as articulações que entre ela e o campo se estabelecem são mais intensas do que nunca, porque não são apenas as relativas à divisão técnica, social e territorial do trabalho, aquelas que orientam as relações entre o rural e o urbano. Trata-se também de articulações que se acentuam, porque estão expressas em formas espaciais em que a cidade e o campo se imbricam, sobrepõe-se, não apenas na escala local, mas em múltiplas escalas". 
sedes de municípios. Os números apresentados nos dão um total de $68,6 \%$ de moradores na zona rural em 1940 e de 63,8\% em 1950.

Muitos colonos, que antes se ocupavam apenas com as lidas do campo, passaram a se estabelecer na zona urbana, passando a trabalhar, principalmente, nas fábricas de calçados $^{12}$. Isso pôde ser observado especialmente a partir da década de 1930, período em que a indústria de calçados começou a se desenvolver consideravelmente.

Analisando a questão do desenvolvimento econômico da região centro-sul, observamos que as áreas de imigração europeia, em especial nessa região do Brasil, conheceram uma maior dinamização econômica, uma vez que procuraram diversificar suas atividades e favoreceram o surgimento de um mercado consumidor de seus próprios produtos, além de não sofrerem a concorrência direta de grandes lavouras tropicais, como ocorreu nas demais regiões do Brasil.

A partir do estudo das transformações sofridas pela economia local, observamos uma forte vinculação desse processo com as mudanças ocorridas no espaço urbano. Tomando como referência o conceito de "cidade industrial", proposto por Tony Garnier e discutido de forma bastante crítica pela historiadora francesa Françoise Choay (2015, p.164), percebemos o quanto a industrialização provocou alterações profundas na constituição e na dinâmica das cidades. Em Sapiranga não foi diferente. A indústria foi, sem dúvida, uma das principais locomotivas do processo de urbanização, que teria sua aceleração a partir da década de 1940.

Cabe lembrar, ainda, que as transformações socioeconômicas alteraram também, significativamente, os hábitos e os costumes da sociedade do início do século XX. A chegada da luz elétrica na década de 1920 e sua ampliação na década de 1940 transformou a vida da localidade ao mudar os hábitos de seus moradores e ao incentivar ainda mais a produção industrial e o desenvolvimento de hábitos considerados cada vez mais "urbanos".

Outro aspecto a ser considerado, nesse mesmo período, é o número de alemães ou naturalizados, que diminui gradativamente ( $R O C H E, 1969)$, ao mesmo tempo em que o número de descendentes de alemães aumentava consideravelmente no estado (eram 21.159 em 1900 e 13.516 em 1950). Portanto, o número de habitantes que se considerava portador da cultura alemã era bastante considerável, especialmente na região do Vale dos Sinos. Assim, a partir do Recenseamento Geral de 1950, podemos perceber as transformações no perfil demográfico do Rio Grande do Sul.

Além disso, o "progresso econômico", experimentado desde o final do século $X I X$ e início do século $X X$, fez com que a integração entre Sapiranga e o centro urbano de São Leopoldo, às margens do Rio dos Sinos, então sede do município, tornasse-se uma realidade.

Um aspecto importante que deve ser lembrado foi o fato de que o intendente de São Leopoldo, no período de 1902 a 1916, Guilherme Gaezler Neto,

\footnotetext{
${ }^{12}$ Consideramos relevante a discussão realizada por Josepa Cucó Giner (2004, p.82) quando afirma que não existe uma polarização entre o rural e o urbano, mas sim um proceso de crescimento gradativo das relações sociais e económicas no espaço urbano. Entretando, segundo a autora o rural e o urbano convivem numa mesma temporalidade, não necesariamente antagônica e simplificadora.
} 
era nascido em Sapiranga. Gaelzer Neto era filho de Henrique Guilherme Gaezler e Maria Sehn Gaezler, adeptos dos Mucker. Naquele ano de 1874, tinha apenas seis meses de vida, tendo sido salvo do campo de batalha contra os Mucker. No período em que administrou o Município de São Leopoldo, realizou várias benfeitorias, como a construção de uma ponte sobre o Rio dos Sinos e outras pontes e estradas na região, o que fez com que conquistasse a simpatia de seus moradores, tendo, ainda, favorecido consideravelmente a localidade de Sapiranga. Guilherme Gaelzer Neto recebeu o apelido de "Pequeno Kaiser", em função da sua semelhança física com o imperador alemão Guilherme II.

Em função do desenvolvimento econômico experimentado por Sapiranga desde o período da administração de Gaelzer Neto, fez-se necessário integrar de forma mais eficiente Sapiranga e a cidade de São Leopoldo, às margens do Rio dos Sinos, então sede do município. Com essa finalidade, foi inaugurado, em 15 de agosto de 1903, mais um trecho da estrada de ferro, unindo, dessa vez, Novo Hamburgo a Taquara, com uma extensão de 43 quilômetros. Estava, portanto, interligada a economia da região com Porto Alegre. ${ }^{13}$

Monteiro (1990) mostrou que, na primeira metade do século $X X$, encontramos fatores excepcionais para o desenvolvimento industrial do país. Para ele, capital, mão de obra, mercado relativamente concentrado, matéria-prima disponível e barata, além da capacidade geradora de energia e um sistema de transportes ligado aos portos favoreceram imensamente a difusão das atividades industriais no Brasil. Essa mesma situação encontramos em Sapiranga no início do século XX e em praticamente todo Vale dos Sinos.

Esses elementos - tomados em sua totalidade - devem ser considerados para explicar o florescimento das atividades tipicamente urbanas na região do Vale dos Sinos, ao mesmo tempo em que acompanhamos o êxodo rural gradativo e o aumento dos centros urbanos com sua consequente diversificação de atividades no setor terciário.

A partir dessa data, com a inauguração da Estação Sapyranga, era possível transportar os produtos até a sede do município, estimulando consideravelmente o incremento da produção, já que o escoamento tornava-se muito mais ágil, rápido e barato. O trem será, portanto, um grande fator para o desenvolvimento da localidade, representando uma nova etapa na história de Sapiranga, que se contrapunha ao passado Mucker, identificado como uma mancha do passado por parte da população. As primeiras décadas do século XX foram marcadas, em Sapiranga, por um grande desenvolvimento na economia e no processo de urbanização.

Lembramos que, além da estrada de ferro, Sapiranga passou a contar com a estrada de rodagem a partir da primeira década do século XX. Essa obra foi realizada por Guilherme Gaelzer Neto, intendente de São Leopoldo. Todavia, o melhoramento das estradas não acompanhou o progresso tecnológico dos meios de transportes, restringindo, inicialmente, o emprego à utilização de caminhões e automóveis, que tiveram sua entrada em Sapiranga ainda na década de 1920. Em razão da larga utilização do trem na região, o meio fluvial de transporte sentiu séria

\footnotetext{
${ }^{13}$ Em 1959, o governo do Estado do Rio Grande do Sul transferiu toda a rede ferroviária para a responsabilidade do governo federal e este acabou desativando toda a rede que ligava as povoações do Vale do Rio dos Sinos, em fins de 1963.
} 
queda em seu uso. Após a década de 1930, o barco a vapor já deixava de ser utilizado. Porém, no período da Segunda Guerra Mundial, as carroças foram novamente muito utilizadas, em razão da escassez de combustível.

O espaço urbano de Sapiranga também sofreu grandes transformações nas primeiras décadas do século $X X$. As origens desse processo vinculavam-se à inauguração da Estação do Trem, ocorrida em 1903. Esse ato favoreceu, em grande parte, a urbanização de Sapiranga ao fazer da Estação o ponto de encontro das atividades econômicas e sociais. Afinal, como aponta o historiador Gilmar Arruda (2000, p.110) "A expansão da ferrovia no Brasil, no século XIX e primeiras décadas deste século [neste caso, o século $X X$ ] parecia não se deter em nenhum obstáculo. Rios, selvas, montanhas foram sendo transpostos [...]".

A produção do espaço urbano (SPOSITO, 2014) sapiranguense sofria sensíveis transformações em sua constituição, apontando para a expansão da rede urbana na localidade e a sua aproximação cada vez maior com os centros urbanos regionais, como São Leopoldo e Porto Alegre, a capital do estado.

Em 1909 foi estendida a linha telefônica até Sapiranga. O aumento da circulação da produção e da circulação de pessoas e mercadorias provocou a instalação de um meio mais rápido e eficaz de comunicação de Sapiranga com as demais localidades. As décadas de 1920 e 1930 conheceram um expressivo crescimento de residências e estabelecimentos comerciais na área urbana, especialmente nas imediações da Estação do Trem.

Nas primeiras décadas do século $X X$, foram perceptíveis o crescimento e a diversificação das atividades comerciais nas redondezas da estação férrea, comprovando o aumento de circulação de pessoas neste núcleo urbano em expansão.

Embora possamos identificar um considerável crescimento industrial e urbano em Sapiranga já nas primeiras décadas do século $X X$, não desconhecemos a realidade vivida pelos moradores dos vales dos Sinos e Caí. De acordo com Jean Roche (1969), essas áreas que compreendiam os municípios de Montenegro, Caí, São Leopoldo, Novo Hamburgo, Taquara e os municípios recentemente criados Canela, Gramado, Nova Petrópolis e Rolante totalizavam uma área total de 5059 hectares quadrados de terra e possuíam, em 1950, uma população de 264.145 habitantes.

A esse contexto de urbanização e de desenvolvimento da vida social dos sapiranguenses somaram-se as repercussões das transformações políticas de âmbito nacional. Os valores nacionais, entendidos como "valores dos brasileiros" 14 foram rejeitados por muitos de seus moradores.

\footnotetext{
${ }^{14}$ Empregamos essa expressão para identificar a forma como muitos moradores de Sapiranga, com ascendência alemã, referiam-se à cultura nacional. Para estes, sua cultura estava diretamente relacionada com a cultura trazida pelos imigrantes alemães. Suas manifestações culturais englobavam desde as danças, músicas, comidas típicas e também a fala da língua alemã. Sobre esta questão da nacionalidade, Lúcia Lippi Oliveira afirma que "no Brasil as mudanças acontecidas na chamada Era Vargas cuidaram de organizar os trabalhadores e procuraram fazê-los participar da sociedade a partir do mundo do trabalho, da carteira profissional, da organização sindical, do Ministério do Trabalho. Por outro lado, foi nesse tempo eu se criou uma identidade simbólica/cultural através de festas cívicas, de feriados, assim como do rádio, do cinema, da propaganda e de biografias do líder maior, Getúlio Vargas." (OLIVEIRA, 2003. p. 67-68)
} 
Um dos aspectos curiosos da sociedade sapiranguense das primeiras décadas do século $X X$ é o fato de que, em razão do desenvolvimento econômico experimentado neste período, os seus hábitos também se modificaram, aumentando gradativamente o poder de consumo de artigos até então considerados supérfluos. Como parte das mudanças em seus hábitos, aparece também a preocupação com o lazer. Isso pode ser percebido especialmente a partir da década de 1930, com as diversas famílias que começam a passar suas férias no litoral norte do estado, principalmente em Tramandaí, onde muitas famílias passam inclusive a adquirir seus próprios imóveis a partir das décadas de 1950. É esse também o período de urbanização do litoral norte do Rio Grande do Sul.

Vale lembrar que as décadas de 1930 e 1940 foram marcadas por várias transformações em nível nacional. Com a Revolução de 1930 e a subida de Getúlio Vargas ao poder presidencial, uma série de mudanças ocorreram. Dentro desse processo, destacamos a nacionalização instituída pelo Estado Novo (1937-1945), por meio do qual se deu início a um forte controle sobre as populações imigrantes no Brasil. Mais precisamente no sul do Brasil, na área de imigração alemã, observamos o rígido controle sobre as pessoas que falavam a língua alemã e que cultivavam suas tradições culturais imigrantes.

Isso não impediu, no entanto, que se observasse, em Sapiranga, uma mudança significativa na denominação de instituições, bem como um controle sobre as manifestações culturais e sobre os próprios hábitos cotidianos da população, que seria exercido pelas autoridades policiais.

Inserida no contexto nacional de transformações políticas (em especial, dos efeitos da campanha da nacionalização de Getúlio Vargas) da década de 1930, a comunidade sapiranguense elegeu o Coronel Genuíno Sampaio como símbolo de manifestação de seu patriotismo. Essa manifestação se deu por meio da denominação da principal escola estadual da cidade e da criação e inauguração do monumento em homenagem ao coronel no morro Ferrabraz, local do conflito Mucker, no século XIX.

Acreditamos que isso se deu, em parte, devido à situação política do Estado brasileiro e de seu empenho para a nacionalização da cultura, em especial nas áreas de imigração, como foi o caso de Sapiranga. Entendidos como uma "ameaça" à cultura nacional, os descendentes de imigrantes alemães de Sapiranga, assim como nas demais áreas do país, foram obrigados a assimilar em suas tradições a cultura entendida como nacional. Com isso, procuraram valorizar os símbolos da nação, em detrimento da cultura germânica, herdada de seus antepassados.

Como exemplos das repercussões dessa política em nível local, tivemos a proibição da fala da língua alemã, bem como a incineração dos livros em alemão, que foram encontrados na Biblioteca da Sociedade de Canto ${ }^{15}$ à época. Dada a necessidade de construção de uma nova identidade cultural para Sapiranga, a comunidade empenhou-se em procurar exemplos de cidadania e patriotismo.

15 Gesangverein Sängerkranz era a denominação original da Sociedade de Canto. Porém, com a instalação do Estado Novo, em 1937, e a proibição da utilização do nome estrangeiro para o clube, este passou a se chamar Clube 19 de Julho, em alusão à data de sua inauguração. O nome encontrado na fachada do prédio, localizado na Avenida João Corrêa, a principal de Sapiranga, teve que ser trocado pelo nome em português. 
No período que se estendeu de 1874 até meados do século $X X$, identificamos muitas transformações e observamos a lenta organização da vida social. No entanto, a formação de sociedades e associações em Sapiranga foi muito mais lenta do que a ocorrida em outras áreas da região do Vale dos Sinos. Esse caráter tardio deveu-se, em parte, ao conflito Mucker, que provocou sentimentos de ódio e de medo entre a comunidade sapiranguense.

Esse quadro foi revertido, em parte, por meio do trabalho desenvolvido por Wilhelm Rotermund, que, com a publicação dos seus Kalender (almanaques), estimulou o desenvolvimento da vida cultural no Vale dos Sinos no início do século XX. Imbuídos de novos ideais e influenciados pelo clima de prosperidade econômica, os moradores de Sapiranga aderiram à organização de sociedades de cunho sociocultural. ${ }^{16}$

Destacamos a importância desses almanaques, que eram vendidos por preços módicos nas comunidades, e assim se transformaram num veículo de cultura entre as populações da região colonial alemã. Estes almanaques circulavam nas casas da população, sendo constantemente emprestados entre os vizinhos, entre os quais também eram motivo de longas conversas. (GRÜTZMANN, 2004)

Chamou-nos atenção a data em que foi fundado o Gesangverein Sängerkranz, dia 19 de julho de 1901, dia e mês em que a casa de Jacobina foi destruída no Ferrabraz. Cremos ser bastante pertinente a associação que pretendemos estabelecer, na medida em que a data era bastante significativa para a comunidade e representava a data em que um episódio da maior relevância para a história do conflito havia acontecido. O simbolismo do passado Mucker parecenos evidente, assim como a intenção de reverenciar a data.

Embora não tenhamos a explicitação dessa intenção nas fontes documentais, impõe-se a forte vinculação entre essas duas datas, a do dia 19 de julho de 1874 e a de 1901. Não seria essa segunda data uma forma simbólica de rememorar a primeira? Acreditamos que sim, já que a ideia de "refundação" da comunidade se fazia muito presente nesse momento, e a ocasião serviu para marcá-la simbolicamente. O passado Mucker, associado ao "regresso" precisava ser apagado na memória dos sapiranguenses, ao mesmo tempo em que se procurava imprimir no imaginário local a ideia do desenvolvimento, representada nesse contexto pelas ideias de "ordem e progresso".

A trajetória percorrida até aqui demonstrou - por meio de um recorte geográfico - que o percurso histórico do desenvolvimento regional deve considerar a "admissão de que aspectos não econômicos contribuem para o desenvolvimento econômico regional, particularmente as práticas culturais e regionais e locais" (VIEIRA; SANTOS, 2012, p.03). Ainda, de acordo com os autores, os historiadores podem permitir, por meio de suas análises que buscam singularizar certos processos locais regionais, na medida em que nos mostram que a " $[\ldots]$

\footnotetext{
${ }^{16}$ Inserida neste espírito, ocorreu, em 1894, a criação das sociedades de canto Gensangverein Bruderbund, no Ratzenberg (atual bairro Amaral Ribeiro) e Gesangverein Liedertafel, no Jakobstal (atual Picada São Jacó) ${ }^{16}$. Anos mais tarde, em 1901, foi fundado o Gesangverein Sängerkranz (Sociedade de Canto "Coroa de Cantores"). Sobre esta questão, Jean Roche (1969) destaca a importância da criação das Sociedades nas áreas coloniais alemãs. De acordo com seu levantamento, encontramos, em 1924, 66 sociedades no Município de São Leopoldo, das quais somente 08 localizavam-se na cidade de São Leopoldo. Das outras, 11 estavam distribuídas no segundo distrito (Novo Hamburgo) e 47, nos demais distritos do município.
} 
consolidação de traços culturais específicos pode impactar sobre as atividades econômicas regionais. Porém, a relação entre as atividades econômicas pertinentes ao desenvolvimento econômico regional e as características culturais presentes na população que ocupava cada região não é mecânica ou determinista" (Ibidem, p.03). Com isso, rompe-se com uma antiga tradição historiográfica, que vinculava o desenvolvimento às suas condições econômicas.

No caso estudado, observamos como os diferentes aspectos - social, político, cultural - estão diretamente relacionados com os aspectos econômicos e não numa simples relação de ordem de superioridade ou inferioridade de importância.

\section{MUDANÇAS NO ESPAÇO: DESENVOLVIMENTO POLÍTICO E CULTURAL}

No período do final do século XIX, observamos transformações no cenário político regional, cujos desdobramentos foram sentidos pela população de Sapiranga. Um exemplo disso foi o Ato Municipal de São Leopoldo no 154, de 28 de março de 1890, que elevou Sapiranga à condição de $5^{\circ}$ Distrito do Município de São Leopoldo.

Já em 02 de maio do mesmo ano, Sapiranga foi elevada à categoria de Freguesia ${ }^{17}$, o que demonstrou que Sapiranga estava num contínuo processo de desenvolvimento econômico ${ }^{18}$, o que muito agradou a São Leopoldo. Anos mais tarde, em 1938, Sapiranga foi elevada à condição de Vila, por intermédio do Decreto Municipal no 7109 de 31 de março de 1938. ${ }^{19}$

Essas mudanças de caráter político comprovam aquilo que já havíamos apontado anteriormente. Sapiranga diversificava progressivamente suas atividades econômicas, uma vez que, na década de 1940, possuía não apenas a produção de calçados, mas também de móveis, massas, sabão, farinha de mandioca, carimbos, artigos de metalurgia, aguardente, vinho e roupas. ${ }^{20}$ Regionalmente, Sapiranga ganhava visibilidade.

\footnotetext{
${ }^{17}$ Durante o Império, Freguesia se constituía numa circunscrição político-administrativa e religiosa. Com a República, há um rompimento entre o Estado e a Igreja Católica. A Freguesia então passa a designar uma circunscrição religiosa, ou seja, lugar onde há uma Igreja Matriz com padre residente. ${ }^{18}$ Logo após a implantação da República, ocorreram diversas transformações na estrutura política do Brasil. Exemplo dessas transformações pode ser percebido em Sapiranga, que foi elevada à condição de Freguesia, em substituição à sua condição anterior de Distrito.

19 Até 1938, havia uma confusão na denominação de vilas e cidades, denominações essas que vinham do período colonial e imperial. Em 1938, o governo federal baixou o Decreto-lei $n^{\circ}$. 311, de 2 de março, que dispôs sobre a divisão territorial no Brasil. Dentre outros, esse decreto estabeleceu normas de âmbito nacional com o objetivo de regrar a questão administrativa dos territórios estaduais. Prescrevia, entre outros aspectos, que as sedes dos municípios teriam a categoria de cidades e que os distritos se designariam pelo nome das respectivas sedes que teriam, a partir de então, a categoria de vila.

${ }^{20}$ O desenvolvimento de Sapiranga torna-se visível se considerarmos os dados presentes nas Estatísticas do Município de São Leopoldo, que nos permitem avaliar os números relativos à produção de Sapiranga.
} 
Tabela 1. Número de estabelecimentos em 1940 (Sapiranga - RS)

Estabelecimentos industriais

Estabelecimentos comerciais

Estabelecimentos de prestação de serviços industriais

Estabelecimentos de prestação de serviços comerciais

Fonte: Dados extraídos de FLECK, 1994. Tabela elaborada pelo autor.

Buscando a ampliação do setor industrial no Brasil, o governo federal aprova a Lei $\mathrm{n}^{\circ} 262$ de 23 de fevereiro de 1948, que estabelece o sistema de licença prévia para as importações. Com isso, ampliam-se ainda mais as possibilidades de produção nacional, visando não apenas ao abastecimento de mercados regionais, mas também à ampliação do volume das exportações. Em termos regionais, o Vale dos Sinos, e consequentemente Sapiranga, tem seus negócios incentivados pela possibilidade das exportações. Como parte importante desse programa nacional de fomento à indústria, Getúlio Vargas, empossado em 31 de janeiro de 1951, lançou um programa de fomento às atividades industriais, matérias-primas e semiprocessadas. Percebemos que o mercado consumidor externo transformou o Vale dos Sinos em um dos principais centros exportadores mundiais de calçado na segunda metade do século $X X$.

Em relação ao sistema de ensino, podemos apontar as cinco escolas primárias estaduais (das quais três eram rurais), as 15 escolas primárias municipais, as cinco escolas primárias particulares (vinculadas às Igrejas) e uma escola de corte e costura mantida pelo SESI.

O desenvolvimento econômico de Sapiranga, especialmente da sua produção agroindustrial, e o empenho pelo progresso ${ }^{21}$ levou seus habitantes a proporem a emancipação política. Nos anos de 1940, Bertholdo José Seibel e Alfredo Sperb, analisando os problemas da Vila e a falta de investimentos por parte de São Leopoldo, fizeram um abaixo-assinado no qual pediam a emancipação de Sapiranga. Tal gesto teve adesão de um número espantoso de pessoas, o que os levou a pensar mais e levar a ideia adiante, realizando um pedido oficial ao governo do Estado, o que foi recusado.

Além disso, não podemos deixar de fazer referência às Assembleias Churrasqueiras, nas quais começaram a tomar forma as ideias sobre a emancipação. Assim, abriu-se, oficialmente, uma campanha pró-emancipação, que se utilizou, inclusive, do jornal local, O FERRABRAZ - fundado em 1949 - para publicar informações e as justificativas para a emancipação da Vila. Dando prosseguimento à campanha de emancipação política, foi realizado o plebiscito no dia 20 de dezembro de 1953, sendo que 1381 eleitores votaram a favor e apenas 96 eleitores votaram contra a emancipação. Assim, encaminhou-se à Comissão de Divisão Territorial do Estado a documentação necessária para a emancipação. Após

\footnotetext{
${ }^{21}$ Neste estudo, o termo progresso é utilizado para caracterizar o desenvolvimento econômico e social alcançado por Sapiranga. Destacamos que esse termo é frequentemente empregado no jornal local para descrever o desenvolvimento econômico e social. Portanto, quando fizermos menção ao progresso de Sapiranga, estamos nos referindo ao desenvolvimento econômico e social, no sentido de expressar o avanço, a civilidade alcançada pela comunidade.
} 
a aprovação dos resultados do plebiscito e pela lei estadual $n^{\circ} 2529$ de 15 de dezembro de 1954, foi criado o Município de Sapiranga, o qual determinava sua instalação para o dia 28 de fevereiro de 1955.

Foi a partir da década de 1940 e 1950 que ocorreu uma notável transformaçãa da estrutura da sociedade sapiranguense. Com a ascensão da indústria, muitas famílias enriqueceram, enquanto que outras se transformaram em fornecedoras de mão de obra para essas indústrias. A estratificação social tornavase um elemento cada vez mais visível na sociedade sapiranguense, algo que nas décadas anteriores não se percebia de forma tão evidente.

Desde a década de 1940, as festas e bailes da comunidade haviam se transformado em "espaços de distinção social" (BOURDIEU, 2001), especialmente verificada com o crescimento da produção de calçados e da metalurgia. Esse desenvolvimento provocou a acentuada diferenciação entre aqueles que detinham o poder econômico e aqueles que estavam subordinados aos meios de produção. Esses espaços sociais - bairros residenciais, cafés, restaurantes, clubes - eram lugares nos quais "ver e ser visto" era algo que fazia parte da dinâmica social sapiranguense.

Nesse meio social, não foram esquecidas as tradições herdadas da descendência alemã. Pelo contrário, o que observamos a partir de meados do século XX foi o convívio de seus moradores com tradições e costumes herdados, tanto por parte da população de origem alemã quanto lusa.

Percebemos importantes transformações na constituição étnica da população do Município de São Leopoldo no início do século XX. Um exemplo disso pode ser constatado nos casamentos realizados, entre os quais se observava um aumento expressivo do número de matrimônios entre pessoas de famílias de origem lusa e alemã. De acordo com Roche (1969), percebemos que o número de moradores que falavam a língua alemã diminuiu a partir da segunda metade do século XX, em parte pela constituição de famílias não mais apenas de origem alemã e também pelas escolas que ensinavam desde cedo a língua portuguesa aos alunos.

Essas tradições podiam ser percebidas através da comemoração do Kerb da cidade, das festas promovidas pelo Clube 19 de Julho e pelas festas religiosas. Os bailes de Kerb, o culto em alemão celebrado na Igreja Evangélica e até mesmo o ensino da língua alemã na escola evangélica faziam parte do conjunto de tradições mantidas pelos sapiranguenses até os dias atuais.

$\mathrm{Na}$ perspectiva de análise das tradições culturais herdadas pelos sapiranguenses de seus antepassados, não podemos deixar de analisar um capítulo quase esquecido da história de Sapiranga, que foi construída basicamente a partir da contribuição da imigração alemã. Referimo-nos à presença do africano e do afrobrasileiro em Sapiranga. Com o propósito de nomear o local ocupado por pessoas de etnia distinta daquela maioria da população (alemã), em especial por aqueles que constituíam a elite local, o bairro África caracterizou-se por concentrar pessoas de origem africana, descendentes de escravos que ali se estabeleceram após a abolição da escravidão. Assim, o grupo étnico negro teve definido o seu espaço no bairro "África", afastado do centro das decisões econômicas, que se desenvolvia nos arredores da Estação do Trem.

Entendemos, portanto, que, ao "criar e nomear" espaços e lugares na cidade de Sapiranga, prevaleceram os interesses que correspondiam aos anseios e valores do grupo dominante local. A reconstrução do bairro África a partir de 
meados do século $X X$ com a denominação de bairro Centenário fazia parte desse processo de construção de Sapiranga como cidade de descendência germânica.

O termo "África", empregado para referir o bairro de população negra em Sapiranga, era recorrente entre seus moradores e até mesmo em documentos oficiais e na imprensa, até meados do século $X X$, quando ocorrerá um crescimento populacional expressivo e essas terras passam a ser valorizadas do ponto de vista imobiliário. Em razão disso, a população negra é deslocada e dispersa para outras áreas. A maioria deixou Sapiranga e buscou moradia em outras regiões do Vale dos Sinos. Atualmente, o Bairro Centenário (antigo bairro África) é uma região bastante valorizada no município e caracteriza-se por residências de classe média. Nesse caso, o desenvolvimento da localidade produziu também uma nova dinâmica de ocupação do espaço, com a reorganização dos grupos sociais no espaço urbano.

Nesse ambiente sociocultural tão diverso, que continuava a sofrer transformações, destacamos a importância do jornal $O F E R R A B R A Z$, fundado em 1949. Por meio de suas propagandas e anúncios, como também de alguns artigos redigidos por pessoas destacadas do meio social sapiranguense, podemos observar o posicionamento da imprensa diante dos acontecimentos que envolviam a vida pública de Sapiranga.

Na década de 1950, ocorreram várias transformações na vida da população sapiranguense. Notamos também que a década de 1960 foi um período em que as atividades urbanas se desenvolveram consideravelmente. Em 1965, o município, que contava com cerca de 15000 habitantes, completou 10 anos de emancipação política.

Até o início da década de 1980, havia em Sapiranga ainda uma relativa concentração da produção e de bens nas mãos das famílias de origem alemã, tanto na agropecuária quanto na indústria. O mesmo pode ser observado na trajetória política de Sapiranga, já que apenas em 1982 teremos o primeiro prefeito de origem lusa. Na mesma proporção, percebemos que tanto os meios de produção quanto o poder político encontravam-se bastante concentrados nas mãos dessas famílias.

\section{CRESCIMENTO INDUSTRIAL E EXPANSÃO DEMOGRÁFICA E SUAS INTERFACES NO DESENVOLVIMENTO}

Concordando com o historiador Maurício Abreu (2014, p.30), observamos que a história de um lugar, como é o caso de Sapiranga "[...] é o resultado da ação, num determinado momento e sobre um determinado espaço, de processos que atuam em escalas que são ao mesmo tempo desiguais e combinadas [...]". De acordo com esse posicionamento, acreditamos que a história desse lugar se relaciona com "[...] escalas mais amplas (regional, nacional, global) da ação humana. Isso não pode ser feito, entretanto, às expensas da compreensão das singularidades locais e da sua devida valorização" (Ibidem, p.30).

Ainda de acordo com Abreu (2014, p.36), é preciso estudar o lugar a partir da recuperação do seu enquadramento espaço-temporal, buscando com isso "o tempo do lugar". Valendo-se dos estudos de Milton Santos, afirma ainda que devemos buscar recuperar o conjunto de temporalidades próprias de cada lugar, que se dá pelo conjunto de técnicas existentes naquele determinado ponto do espaço que se está analisando. 
Os anos entre 1960 e 1990 experimentaram um expressivo crescimento industrial vinculado ao aumento da oferta de trabalho no município. Considerado como um município de crescimento expressivo no Rio Grande do Sul, Sapiranga atraiu muitas pessoas de outras regiões do estado, especialmente a partir da década de 1970. Em 1966, ocorreu a $1^{a}$ Exposição Industrial de Sapiranga, que procurava mostrar aos visitantes o desenvolvimento econômico do município. Por ocasião da segunda exposição industrial e da $4^{a}$ Festa das Rosas, ocorrida em 1967, Dante de Laytano escreveu no Jornal do Comércio sobre o desenvolvimento do município. Num trecho de seu artigo, ele afirma: "Quanta coisa tem Sapiranga. Seu colégio, seus colégios [...]. A paisagem de vales sempre verdes, como era verde meu vale. E as ruas de Sapiranga que tem canteiros de rosas. Oh! Cidade das rosas." (Jornal do Comércio, 23 nov. 1967. Capa)

Atrelado a esse contexto de progresso econômico, ocorreu um expressivo aumento da população $e$, consequentemente, o aumento das atividades desenvolvidas no meio urbano. ${ }^{22}$ Porém, à medida que a população sapiranguense aumentava e desenvolvia sua economia, novos problemas sociais surgiram, como a violência e a segurança pública.

Nessa fase de progresso econômico, teve início a festa mais popular de Sapiranga, que homenageava a flor mais cultivada nos canteiros dos jardins sapiranguenses. Era a "Festa das Rosas", criada oficialmente por meio do Decreto Municipal no 604 de 04 de novembro de 1964.

A falta de planejamento e infraestrutura urbana provocou o surgimento de áreas periféricas, desprovidas de qualquer melhoria e nas quais surgiram favelas. Esse mesmo crescimento econômico pode ser observado nos demais municípios do Vale do Sinos, em especial em Novo Hamburgo e Campo Bom. Essas áreas conheceram um crescimento muito acelerado de sua economia ao mesmo tempo em que assistiram ao aumento da concentração da renda e ao inchamento de áreas periféricas sem nenhuma infraestrutura urbana para essas populações recémchegadas de outros municípios do Rio Grande do Sul, em especial de Frederico Westphalen, Seberí, Vicente Dutra, Mata e Palmeira das Missões.

Devido a esse crescimento industrial e à falta de planejamento das décadas de 1970 e 1980, a sociedade sapiranguense enfrentava sérios problemas relacionados à moradia, à alimentação, à saúde pública e à falta de escolas para a população migrante. Por meio da imprensa sapiranguense, podemos acompanhar os problemas que surgiam com o crescimento industrial do município. Manchetes evidenciavam os problemas relacionados à falta de moradia e à pobreza que assolava essas novas famílias que se estabeleciam diariamente no município. A partir da década de 1970, torna-se impressionante a quantidade de edições nas quais foram publicadas as fotografias de pessoas identificadas como "bandidas" e "assassinas" e autoras de diversos tipos de delitos.

As manchetes retratando crimes e atos de vandalismo são uma constante na imprensa a partir desse momento. Também o movimento migratório intenso para Sapiranga assustava os moradores antigos além de causar preocupação nas

22 Em razão do novo contexto de grande desenvolvimento econômico do Vale do Sinos e do aumento da população nesse período, Sapiranga sofreu três grandes reduções do seu território. Isso se deu em função da emancipação de três novos municípios, como Parobé, em 1988, Nova Hartz, em 1992 e Araricá, em 1997. 
autoridades municipais. Exemplo dessa afirmação pode ser encontrado na manchete publicada no dia 05 de novembro de 1982 cujo título em letras com destaque chamava a atenção do leitor: MIGRAÇÃO CONTINUA SENDO PROBLEMA EM SAPIRANGA. Nessa mesma edição, ainda foi publicada uma matéria intitulada O CRESCIMENTO DEMOGRÁFICO, que alertava o leitor para o controle da taxa de natalidade e os problemas de crescimento desordenado nos países subdesenvolvidos. (O FERRABRAZ, 05 nov. 1982. ano XXXII).

No final do século $X X$, a sociedade sapiranguense era formada não mais por uma população majoritariamente de descendência alemã. Incorporou novos costumes, que não mais apenas aqueles herdados pelos imigrantes alemães. A nova realidade social em Sapiranga demonstrava o processo de assimilação dos costumes trazidos pelos novos moradores de descendência lusa, que haviam migrado nas décadas de 1970 e 1980.

Sobre essa dinâmica de transformações, podemos retomar o estudo realizado por Giner (2004). Para a antropóloga, os bairros de uma cidade, ocupados por diferentes sujeitos de diferentes origens tendem a estabelecer relações conflituosas, na medida em que os lugares que esses sujeitos ocupam passam a ser muito diferentes, como é o caso da estratificação social.

De acordo com a autora, esses sujeitos estabelecem, ao mesmo tempo, marcos de interação e cooperação. Podem construir identidades que afirmam, por exemplo, suas diferenças étnicas, como no caso de Sapiranga, entre aqueles que eram considerados "alemães" e os não alemães, que vinham de outras regiões do estado para trabalhar na indústria.

Isso pode ser percebido pelos diferentes aspectos da vida social dos moradores do município, tais como a diversificação de suas práticas religiosas (com a fundação de novas congregações no município), a criação de novas associações de bairros e suas festas anuais, o declínio da fala da língua alemã, bem como a participação cada vez maior de sobrenomes lusos nas atividades políticas e também econômicas, mostrando que muitos daqueles migrantes também conquistaram riqueza no novo município.

O vôo livre e a prática do para-glider transformaram-se em esportes bastante conhecidos na cidade, levando Sapiranga inclusive a sediar campeonatos nacionais desses esportes no morro Ferrabraz. Ainda como elementos novos que fizeram parte da realidade dos moradores de Sapiranga na década de 1980, podemos citar a inauguração do Loteamento $\mathrm{COHAB}$, que criou casas populares para a população de baixa renda do município. Ainda nessa década, seria inaugurado o Parque do Imigrante, que, por meio da sua denominação, homenageou os imigrantes alemães, os quais iniciaram ainda no século XIX o povoamento de Sapiranga.

No início do século XXI, a cidade de Sapiranga apresentava uma economia que merecia destaque nacional, por sua condição de produtora de calçados de destaque e por uma população essencialmente urbana. De acordo com os dados do Instituto Brasileiro de Geografia e Estatística - IBGE (2010), Sapiranga possui uma área total de $137,5 \mathrm{Km}^{2}$ e uma população de 74.985 habitantes. Sua densidade demográfica é de 542,13 hab/ $\mathrm{Km}^{2}$. Outros dados revelam o índice de desenvolvimento e sua população, tais como a taxa de analfabetismo, que, em 2000 , era de 5,85\%, e a expectativa de vida ao nascer no município era nesse 
mesmo ano de 73,82 anos. A taxa de mortalidade infantil, em 2005, era de 11.24 por mil nascidos vivos. Em termos socioeconômicos, temos para Sapiranga um Produto Interno Bruto - PIB de R\$ 992 milhões, um PIB per capita de R\$12,8 mil (2010).

As exportações (essencialmente de calçados) totalizaram US\$ 164 milhões em 2010. Segundo o IBGE, Sapiranga apresenta ainda, de acordo com as estatísticas oficiais de 2010, um potencial de consumo de $\mathrm{R} \$ 1,2$ bilhão. Ainda, segundo o Cadastro Central de Empresas do IBGE de 2012, Sapiranga empregava 30.427 trabalhadores em 3.855 empresas atuantes. Vale ressaltar que, segundo o Cadastro, a renda média dos sapiranguenses na indústria é de aproximadamente dois salários mínimos, ou seja, uma renda considerada baixa.

Atualmente, como alternativa aos setores tradicionais da indústria, especialmente por iniciativa da prefeitura municipal, Sapiranga procura inserir-se no roteiro histórico-cultural do Vale do Sinos. Para tanto, a administração municipal procura destacar de forma bastante expressiva seu passado Mucker, como observado na criação d' Os caminhos de Jacobina, em 2001, numa parceria estabelecida entre o poder público municipal e o Serviço Brasileiro de Apoio às Micro e Pequenas Empresas - SEBRAE-RS.

Os Caminhos de Jacobina compreende um roteiro turístico que se inicia no centro da cidade, passando por diversos lugares da cidade até chegar à zona rural, onde os visitantes podem conhecer os locais das batalhas, cemitério, monumentos e a Colônia Jacobina, onde foram realizadas as gravações de parte do filme $A$ paixão de Jacobina. Todos os locais compreendidos nesse roteiro estão devidamente identificados por placas indicativas que têm no alto a imagem estilizada de Jacobina. Recentemente, no ano de 2006, foi inaugurado o último ponto turístico desse roteiro. Trata-se do monumento em homenagem a Jacobina Maurer, situada logo na entrada da cidade.

Se, no passado, os Mucker eram interpretados como uma mancha que deveria ser apagada da memória da população sapiranguense, atualmente eles são resgatados para o desenvolvimento do setor do turismo, angariador de recursos financeiros e facilitador da projeção da cidade no cenário nacional.

O espaço se transformou, assim como seus personagens. O lugar que recebeu os imigrantes alemães no século XIX, até os dias atuais, sofreu significativas mudanças. A identidade étnica deixou de ser um traço importante para a cidade, na medida em que observamos, na atualidade, que a maioria dos moradores de Sapiranga não são mais de origem germânica. Ao contrário, a sociedade local é constituída hoje de elementos de diferentes origens, resultado dos complexos processos migratórios das últimas décadas no Rio Grande do Sul e no Brasil.

Nesse contexto de mudanças, é pertinente lembrar os impactos que os processos migratórios e o desenvolvimento da indústria provocaram na cidade. A estratificação social e a segmentação desses grupos nos espaços das cidades conferiram a Sapiranga características que definem os espaços daqueles que prosperaram e daqueles que foram, de certa maneira, excluídos do processo de desenvolvimento econômico da cidade. A existência de bairros operários no seu espaço urbano é um elemento concreto desse processo, que aproxima ideias de exclusão e violência na escala local. 
Sapiranga, considerado um dos maiores municípios produtores e exportadores de calçado do Brasil, revela, em sua especificidade territorial, características que o aproximam bastante de outros municípios vizinhos do Vale do Sinos, onde as marcas do calçado provocaram impactos decisivos na trajetória de desenvolvimento. Compreendemos que a história desse processo - analisada em âmbito microespacial nos permite ver suas pecualiaridades - também nos revela características daquilo que lanni (1999) já chamava de globalismo dos dias atuais.

\section{CONSIDERAÇÕES FINAIS}

Discutir sobre o percurso histórico do desenvolvimento regional, a partir de uma situação-problema, no Vale do Sinos, permitiu melhor compreender aquilo que Vieira e Santos (2012) afirmam, quando se referem à necessidade de se deslocar o eixo de análise para além do aspecto econômico. Para eles, há uma real necessidade de se incorporar novas variáveis - qualitativas - que ultrapassem a barreira econômica. Ainda, de acordo com os autores, é necessário que a análise crítica sobre os processos de desenvolvimento regional seja "[...] repensada e reclassificada em outras categorias, como as realizações feitas com os recursos disponíveis na busca da produtividade social [...]" (ibidem, p.366-367). Impõe-se, ainda, que a análise deve estar alicerçada "[...] no estabelecimento de valores conforme a cultura local, nas relações sociais entre os indivíduos da região e o ambiente no qual está inserido [...]" (Ibidem, p.367).

Assim sendo, a história do desenvolvimento regional, compreendida por meio de um recorte espacial, que é Sapiranga, nos permitiu discutir os mecanismos presentes em seu processo de constituição. Desde os tempos do final do século XIX, quando a comunidade viu-se abalada pelo conflito dos Mucker até o começo do século XXI, notamos que o espaço passou por mudanças sensíveis.

A agricultura, a indústria e o surgimento do turismo na cidade marcam momentos distintos do processo histórico do desenvolvimento econômico de Sapiranga, que fizeram surgir novos elementos, como o impulso da urbanização, a chegada dos novos moradores - especialmente como resultado dos movimentos migratórios das décadas de 1970 e 1980 - e a diversificação das atividades econômicas, que produziram no âmbito local uma nova dinâmica de funcionamento dessa urbe. Com isso, "[...] a representação do espaço carrega uma certa periodização [...]" (ARRUDA, 2000, p.167) e na qual "[...] tempo e espaço são considerados conjuntamente [...]" (Ibidem, p.167).

Conhecer o passado que constitui a dinâmica do desenvolvimento regional, a partir das especificidades locais, como nos lembra o economista e pesquisador do desenvolvimento regional Carlos Paiva (2013), permite melhor conhecer as características do espaço em questão e promover novas estratégias de desenvolvimento. Com isso, a história do desenvolvimento regional nos permite não apenas conhecer o passado - aquilo que já existiu - mas pensar e planejar estratégias que avançam, sem com isso, desconsiderar a historicidade e os traços identitários presentes na memória dessas comunidades, preocupadas na atualidade com o seu desenvolvimento.

A pesquisa empreendida aqui nos permitiu, ainda, descortinar o universo no qual se inserem as categorias local e regional, pensando as especificidades de Sapiranga articuladas e pensadas num contexto regional, que é o Vale do Sinos - 
região conhecida pela sua tradição coureiro-calçadista - no Rio Grande do Sul e no Brasil.

\section{REFERÊNCIAS}

ABREU, Maurício. Sobre a memória das cidades. In: CARLOS, Ana Fani A. et al. (orgs). A produção do espaço urbano: agentes e processos, escalas e desafios. São Paulo: Contexto, 2014. p.19-40.

ALONSO, José A. F. A persistência das desigualdades regionais no RS: velhos problemas, soluções convencionais e novas formulações. Indic. Econ. FEE, Porto Alegre, v. 33, n. 4, p.101-114, mar. 2006.

AMADO, Janaína. Conflito social no Brasil: a revolta dos "Mucker". São Paulo: Símbolo, 1978. 304p.

ANSART, Pierre. História e memória dos ressentimentos. In: BRESCIANI, Stella; NAXARA, Márcia (Org.). Memória e (res)sentimento: indagações sobre uma questão sensível. Campinas: UNICAMP, 2004. p.15-36.

ARRUDA, Gilmar. Cidades e sertões: entre a história e a memória. Bauru: EDUSC, 2000. 256p.

BACZKO, Bronislaw. Imaginação social. In: ENCICLOPÉDIA Einaudi(AnthroposHomem). Portugal: Imprensa nacional/Casa da Moeda, s/d. v. 5. p. 307-308.

BANDEIRA, Pedro. Participação, Articulação de Atores Sociais e Desenvolvimento Regional. Brasília: IPEA, 1999. 89p.

BARROS, José D'Assunção. Cidade e história. Petrópolis: Vozes, 2007.124p.

BIASE, Alesia de. Ficções arquitetônicas para a construção da identidade.

Horizontes Antropológicos, Porto Alegre, v. 7, n. 16, dez. 2001. p.173-188.

BOSI, Ecléa. Memória e sociedade: lembranças de velhos. 3. ed. São Paulo: Companhia das Letras, 1994. 484p.

BOURDIEU, Pierre. Razões práticas: sobre a teoria da ação. Campinas, SP: Papirus, 1996. 224p.

. A Economia das trocas lingüísticas. 2. ed. São Paulo: EDUSP, 1998 . 188p.

O Poder simbólico. 4. ed. Rio de Janeiro: Bertrand, 2001. 311p.

BRANDÃO, Carlos A. L (Org). As Cidades da cidade. Belo Horizonte: UFMG, 2006. 197p. 
BRESCIANI, Stella; NAXARA, Márcia (Orgs.). Memória e (res)sentimento: indagações sobre uma questão sensível. Campinas: UNICAMP, 2004. 554p.

CARVALHO, José Murilo de. A formação das almas: o imaginário da república no Brasil. São Paulo: Companhia das Letras, 1998.166p.

CAVALCANTI, Lana de Souza. Geografia da cidade: a produção do espaço urbano em Goiânia. Goiânia: Alternativa, 2001. 237p.

CHOAY, Françoise. O Urbanismo: utopias e realidades, uma antologia. 7 ed. São Paulo: Perspectiva, 2015. 350p.

CHOAY, Françoise. A Alegoria do patrimônio. São Paulo: UNESP, 2001. 282p.

DELGADO, Andréa Ferreira. Goiás: a invenção da cidade "patrimônio da humanidade". Horizontes Antropológicos, Porto Alegre, v. 11, n. 23, jan./jun. 2005. p.113-143.

DINIZ, Clélio Campolina. Celso Furtado e o desenvolvimento regional. Nova econ., Belo Horizonte, v. 19, n. 2, set. 2009 . Disponível em $<$ http://www.scielo.br/scielo.php?script=sci_arttext\&pid =S010363512009000200001\&lng=pt\&nrm=iso >. Acesso em 04 jul. 2014. http://dx.doi.org/10.1590/S0103-63512009000200001.

FAUSTO, Boris. História concisa do Brasil. São Paulo: USP/Imprensa Oficial do Estado, 2002. 324p.

FLECK, Lúcio. História de Sapiranga. Santa Maria, RS: Pallotti, 1994. 311p.

FORTES, Amyr Borges; WAGNER, João Baptista Santiago. História Administrativa, Judiciária e Eclesiástica do Rio Grande do Sul. Porto Alegre: Globo, 1963. 496p.

GINER, Josepa Cuco. Antropologia urbana. Barcelona: Ariel, 2004. 244p.

GRÜTZMANN, Imgart. O almanaque (Kalender) na imigração alemã na Argentina, no Brasil e no Chile. In: DREHER, Martin et al. (orgs.) Imigração e imprensa. Porto Alegre: EST/ São Leopoldo: IHSL, 2004. p. 48-90.

HAESBAERT, Rogério. Regional-Global. Dilemas da região e da regionalização na Geografia Contemporânea. 2 ed. Rio de Janeiro: Bertrand Brasil, 2014. 210p.

HALBWACHS, Maurice. A Memória coletiva. São Paulo: Centauro, 2004. 197p.

IANNI, Octavio. A era do globalismo. 4 ed. Rio de Janeiro: Civilização Brasileira, 1999. 256p.

JOVCHELOVITCH, Sandra. Representações sociais e esfera pública. A construção simbólica dos espaços públicos no Brasil. Petrópolis: Vozes, 2000. 232p. 
LE GOFF, Jacques. História e memória. 5 ed. Campinas: UNICAMP, 2003. 541p.

LIMA, Antonio E. M. A Teoria do Desenvolvimento Regional o papel do Estado. Análise Econômica. Faculdade de Ciências Econômicas da UFRGS, Porto Alegre. Ano 24, n. 45, p.65-90. mar, 2006.

LIMA, Henrique Espada. A Micro-história italiana: escalas, indícios e singularidades. Rio de Janeiro: Civilização Brasileira, 2006. 528p.

MENESES, José Newton Coelho. História \& turismo cultural. Belo Horizonte: Autêntica, 2004. 127p.

MOEHLECKE, Germano Oscar. O Vale do Sinos era assim. São Leopoldo: Rotermund, 1978. 360p.

MONTEIRO, Hamilton de Mattos. Da República Velha ao Estado Novo. Parte A: o aprofundamento do regionalismo e a crise do modelo liberal. In: LINHARES, Maria Yedda (Org.). História geral do Brasil. 9. ed. Rio de Janeiro: Elsevier, 1990. p. 302315.

MOREIRA, Paulo Roberto Staudt. Feiticeiros, venenos e batuques: religiosidade negra no espaço urbano (Porto Alegre - século XIX). In: GRIJÓ, Luiz Alberto et ali (orgs). Capítulos de História do Rio Grande do Sul. Porto Alegre: UFRGS, 2004. p. 147-178.

MUMFORD, Lewis. A cidade na história: suas origens, transformações e perspectivas. São Paulo: Martins Fontes, 1998. 741p.

NORA, Pierre. Entre memória e história: a problemática dos lugares. Projeto História, São Paulo, n. 10, dez. 1993. p. 07-28.

OLIVEIRA, Lúcia Lippi. A construção do herói no imaginário brasileiro de ontem e hoje. In: PESAVENTO, Sandra Jatahy (org.). História cultural. Experiências de Pesquisa. Porto Alegre: UFRGS, 2003. p. 67-68.

OLIVEIRA, Gilson B. de.; LIMA, José E. de Souza. Elementos endógenos do desenvolvimento regional: considerações sobre o papel da sociedade local no processo de desenvolvimento sustentável. Revista FAE, Curitiba, v.6, n.2, p.29-37, maio/dez. 2003.

PAIVA, Carlos A. N. Fundamentos da análise e do planejamento de economias regionais. Foz do Iguaçu: Editora Parque Itaipu, 2013. 203p.

PESAVENTO, Sandra Jatahy. Palavras para crer: imaginários de sentido que falam do passado. Nuevo Mundo Mundos Nuevos, n. 6, 2006. Disponível em $<$ http://nuevomundo.revues.org/document1499.html>. Acesso em 19 mai. 2014. 
PORTO, Aurélio. O trabalho alemão no Rio Grande do Sul. Porto Alegre: Est. Graf. S. Terezinha, 1934. 277p.

PRADO JÚNIOR, Caio. História econômica do Brasil. São Paulo: Brasiliense, 2004. $364 p$.

ROCHE, Jean. A Colonização alemã e o Rio Grande do Sul. Porto Alegre: Globo, 1969. 2 v.

SANTOS, Elinaldo L. et al. Desenvolvimento: um conceito multidimensional. Desenvolvimento Regional em Debate, Contestado, v.02. n.01. p. 44-61, jul.2012.

SCHRÖDER, Ferdinand. A imigração alemã para o sul do Brasil até o ano de 1859. 2. ed. Porto Alegre: EDIPUCRS / São Leopoldo: UNISINOS, 2003. 170p.

SIMPÓSIO DE HISTÓRIA DA IMIGRAÇÃO E COLONIZAÇÃO ALEMÃ NO RIO GRANDE DO SUL, 1., 1974. Anais... São Leopoldo: Rotermund, 1974.

SOARES, Mozart Pereira. O Positivismo no Brasil: 200 anos de Augusto Comte. Porto Alegre: AGE/UFRGS, 1998. 206p.

SPOSITO, Maria Encarnação B. A produção do espaço urbano: escalas, diferenças e desigualdades socioespaciais. In: In: CARLOS, Ana Fani A. et al. (orgs). $A$ produção do espaço urbano: agentes e processos, escalas e desafios. São Paulo: Contexto, 2014. p.123-146.

THEODORO, Janice. Canudos 100 anos depois: da vida comunitária ao surgimento dos movimentos fundamentalistas. In: ABDALA JÚNIOR, Benjamin e ALEXANDRE, Isabel (orgs.). Canudos: palavra de Deus sonho da terra. São Paulo: SENAC; São Paulo/ Boitempo Editorial, 1997. p. 119-136.

TRAMONTINI, Marcos Justo. A organização social dos imigrantes: a colônia de São Leopoldo na fase pioneira 1824 - 1850. São Leopoldo: UNISINOS, 2000. $424 p$.

VAINFAS, Ronaldo. Micro-história. Os Protagonistas Anônimos da História. Rio de Janeiro: Campus, 2002. 163p.

VIEIRA, Edson T.; SANTOS, Moacir J. dos. Desenvolvimento econômico regional uma revisão histórica e teórica. Revista Brasileira de Gestão e Desenvolvimento Regional. Taubaté, SP, v. 08. n. 02. p. 344-369. mai/ago. 2012.

WASSERMAN, Claudia. O Rio Grande do Sul e as elites gaúchas na Primeira República: guerra civil e crise no bloco do poder. In: GRIJÓ, Luiz Alberto et al (Org.). Capítulos de História do Rio Grande do Sul. Porto Alegre: UFRGS, 2004. p. 273-290. 
Submetido em 07/07/2014

Aprovado em 13/04/2016

Sobre o autor

Daniel Luciano Gevehr

Doutor em História. Professor do Programa de Pós-Graduação em Desenvolvimento Regional (PPGDR) das Faculdades Integradas de Taquara (FACCAT).

Endereço para correspondência: Avenida Oscar Martins Rangel, 4500 (ERS115). Bairro Fogão Gaúcho. 95600000 - Taquara - RS.

E-mail: danielgevehr@hotmail.com 